\title{
The Prevalence of Alzheimer's Disease and Dementia in Alzheimer's Disease in Patients of Long-Term Nursing Home Care in the Podlaskie Province in Poland
}

\author{
Wieslawa Mojsa \\ Department of Family Medicine and Community Nursing, Medical University of Bialystok, Bialystok, Poland \\ Email: wmojsa@onet.pl
}

Received 22 May 2015; accepted 30 August 2015; published 4 September 2015

Copyright (C) 2015 by author and Scientific Research Publishing Inc.

This work is licensed under the Creative Commons Attribution International License (CC BY). http://creativecommons.org/licenses/by/4.0/ (c) (i) Open Access

\begin{abstract}
The prevalence of Alzheimer's disease and dementia in Alzheimer's disease according to the International Statistical Classification of Diseases and Related Health Problems ICD-10 in patients of long-term nursing home care in the Podlaskie province is not yet known. The aim of the study was the socio-demographic assessment of the long-term nursing home care patients with diagnosed Alzheimer's disease and socio-demographic assessment of the long-term nursing home care patients with dementia in Alzheimer's disease. Data concerning all 7637 patients who received longterm nursing home care benefits in the years from 2008 to 2013 in the Podlaskie province were investigated. Alzheimer's disease was diagnosed in $2.972 \%$ of patients at the average age of 79.82 years $( \pm 8.05)$. The disease was diagnosed more frequently $(\mathbf{7 8 . 4 \% )}$ ) and earlier in women (from 44 years of age). Dementia in Alzheimer's disease was diagnosed in 210 patients $(2.749 \%)$. The mean age of patients with Alzheimer's dementia was 81.72 years $( \pm 7.73)$. Stupor in patients under 65 years more frequently affected women. Research confirms the impact of Alzheimer's disease and dementia in Alzheimer's disease on daily activity performance. Studies suggest that the high rate of Alzheimer's disease and dementia in Alzheimer's disease is due to ethnic and national differences associated with learning at home and in schools in the Podlaskie province.
\end{abstract}

\section{Keywords}

Alzheimer's Disease, Neurodegenerative Dementia, Socio-Demographic, Epidemiology, Poland 


\section{Introduction}

Alzheimer's disease is included in the International Statistical Classification of Diseases and Related Health Problems ICD-10, published by the World Health Organization in 2009, in Chapter VI-Diseases of the nervous system (G00-G99). This chapter shows the classification group G30-G32, which specifies other degenerative diseases of the nervous system, with G30 indicating Alzheimer's disease. Alzheimer's disease is a primary degenerative brain disorder of unknown etiology with neurochemical and neuropathological features. Alzheimer's disease includes the elderly forms and younger forms and these forms are compatible with World Health Organization protocol. The disease onset is difficult to determine. Dementia in Alzheimer's disease is described in Chapter V-Mental and behavioral disorders, containing the classification group F00-F99 of mental development disorders. Dementia in Alzheimer's disease is specified in F00.

Early-onset dementia in Alzheimer's disease under the age of 65 is characterized by rapid progress and associated with numerous disorders of higher functions of the cerebral cortex, including thinking, learning ability, linguistic capacity and judgments. Dementia in Alzheimer's disease with an onset over the age of 65, usually in the late 70s or later in life and slow in its course, is characterized by impaired orientation, comprehension and others, with memory impairment as the major feature [1]. The pathogenesis of Alzheimer's disease is socio-demographic, culture, nationality, family behavior patterns and geographic regional location lead to the disease prevalence [2] [3]. Alzheimer's disease develops in stages, each stage being characterized by enhanced disorders in the following three areas: cognition, behavior and activities of daily living performance (ADLs) [2].

The long-term nursing home care is provided regularly by nurses at patients' homes as part of health benefits. The service is offered to chronically ill and dysfunctional patients regardless of age, number and type of chronic diseases, whose Barthel ADL Index does not exceed the score of 40. This scale allows the assessment of the level of independence to perform basic activities of daily living such as eating, moving around, mobility, and the ability to maintain personal hygiene and to control physiological functions. Terms of contracting services of long-term nursing home care are defined by the National Health Fund managing health insurance finances [4].

The Podlaskie province is located in the north-east of Poland, in the geographical center of Europe and at the border with Belarus of over 200 kilometers (the border of the EU) and Lithuania of over 100 kilometers long. According to the Statistical Office in Bialystok (the capital city of the Podlaskie province), there were 1,201,000 people living in the Podlaskie province in 2012 [5]. In 2011, the urban population was the majority (60.3\%), with a slight predominance of women (51.1\%). As shown by the Statistical Office in Bialystok, $11 \%$ of the Podlasie inhabitants declared to have impaired ability to perform daily living activities. Women accounted for $53.8 \%$ and men for $46.2 \%$ of the disabled. The predominant population of the Podlaskie province (92.1\%) shared a homogeneous Polish national identity.

Only $1.3 \%$ of the Province inhabitants declared other than Polish national identity that $2.8 \%$ had only non-Polish nationality and ethnicity, with some people identifying themselves with two non-Polish nationalities. Nationality was not defined in 3.8\% of the Province inhabitants. Among the foreigners living in the Podlaskie province, Belarussians are the predominant group (46.9\% of their total number), followed by Russians (13.8\%), Ukrainians (6.7\%) and Armenians (5.0\%). The majority of the province population (except for the Polish nationality) most often identify themselves to be of Belarusian, Lithuanian and Ukrainian nationality. The vast majority of Podlaskie inhabitants speak only Polish language (88.6\%) in households, 3.2\% —other than Polish and $0.7 \%$ - one or two non-Polish languages [6]. Additionally, in some towns there are nursery and primary schools with Belarusian language of teaching, mainly in Bielsk Podlaski and Hajnówka.

The aim of the research was:

- the socio-demographic assessment of long-term nursing home care of patients with diagnosed Alzheimer's disease;

- the socio-demographic assessment of long-term nursing home care of patients with diagnosed dementia in Alzheimer's disease.

\section{Materials and Method}

\subsection{Study Design}

The analyzed data were obtained from the Podlasie Branch of the National Health Fund in Bialystok concerning all patients (7637 people) who benefited from long-term nursing home care in the years 2008-2013 in the prov- 
ince.

\subsection{Setting-Participants}

The study used data of 7637 patients living in the Podlaskie province, both in urban and rural areas of a total area of $20,187 \mathrm{~km}^{2}$ in the northeastern part of Poland. The region's capital is the city of Bialystok.

\subsection{Study Procedure}

Data were collect compatible with the National Health Fund in Poland procedure. Data were analyzed with respect to age, gender of patients diagnosed with Alzheimer's disease and dementia in Alzheimer's disease according to the International Statistical Classification of Diseases and Related Health Problems ICD-10.

\subsection{Ethical Considerations}

The study protocol was approved by the Ethical Committee at the Medical University of Bialystok (decision No. RI-002/69/2015). Data were analyzed anonymously with personal data protection.

\subsection{Statistical Analysis}

The results obtained were analyzed statistically. The arithmetic mean and standard deviation were calculated for measurable characteristics, whereas the quantitative-percentage distribution was determined for qualitative features. Student's t-test was used for measurable traits to compare between the selected groups, and $\mathrm{CHi}^{2}$ independence test for qualitative features. The level of statistical significance was considered at $p<0.05$. Calculations were performed using the SPSS statistical package.

\section{Results}

As shown in Table 1, neurological diseases marked with the letter G were diagnosed in 1299 people (17.009\%), while mental and behavioral disorders marked with the letter $\mathrm{F}$ were diagnosed in 838 patients (10.973\%).

Table 1. Disease diagnosis rate by international statistical classification of diseases and related health problems ICD-10.

\begin{tabular}{ccc}
\hline ICD-10 & Frequency $(\mathrm{N})$ & Percent $(\%)$ \\
\hline I & 2815 & 36.860 \\
G & 1299 & 17.009 \\
L & 851 & 11.143 \\
F & 838 & 10.973 \\
S & 460 & 6.023 \\
E & 376 & 4.923 \\
M & 303 & 3.968 \\
C & 206 & 2.697 \\
N & 105 & 1.375 \\
J & 102 & 1.336 \\
T & 83 & 1.087 \\
K & 62 & 0.812 \\
Z & 46 & 0.602 \\
D & 36 & 0.471 \\
R & 25 & 0.327 \\
Q & 14 & 0.183 \\
H & 6 & 0.079 \\
A & 4 & 0.052 \\
B & 3 & 0.039 \\
Y & 2 & 0.026 \\
V & 1 & 0.013 \\
Total & 7637 & 100.0 \\
\hline & &
\end{tabular}


Among all the 7637 surveyed patients, Alzheimer's disease (G30) was diagnosed in 227 people (2.972\%). It was diagnosed more frequently and earlier in women (78.4\%, over the age of 44$)$ as compared to men (21.6\%, over 60 years old). As shown in Table 2, women were systematically diagnosed with Alzheimer's disease, up to

Table 2. The prevalence of Alzheimer's disease (G30) by age and gender.

\begin{tabular}{|c|c|c|c|}
\hline \multirow{2}{*}{ Age (years) } & \multicolumn{2}{|c|}{ Gender } & \multirow{2}{*}{ Total (N) } \\
\hline & Women (N) & Men (N) & \\
\hline 44 & 1 & 0 & 1 \\
\hline 56 & 3 & 0 & 3 \\
\hline 57 & 2 & 0 & 2 \\
\hline 58 & 1 & 0 & 1 \\
\hline 60 & 1 & 1 & 2 \\
\hline 61 & 2 & 0 & 2 \\
\hline 62 & 3 & 0 & 3 \\
\hline 63 & 1 & 0 & 1 \\
\hline 67 & 1 & 0 & 1 \\
\hline 68 & 1 & 0 & 1 \\
\hline 70 & 2 & 0 & 2 \\
\hline 71 & 2 & 0 & 2 \\
\hline 72 & 1 & 2 & 3 \\
\hline 73 & 3 & 0 & 3 \\
\hline 74 & 4 & 3 & 7 \\
\hline 75 & 6 & 5 & 11 \\
\hline 76 & 4 & 7 & 11 \\
\hline 77 & 10 & 6 & 16 \\
\hline 78 & 12 & 4 & 16 \\
\hline 79 & 14 & 4 & 18 \\
\hline 80 & 10 & 2 & 12 \\
\hline 81 & 8 & 3 & 11 \\
\hline 82 & 14 & 1 & 15 \\
\hline 83 & 11 & 0 & 11 \\
\hline 84 & 10 & 3 & 13 \\
\hline 85 & 9 & 0 & 9 \\
\hline 86 & 9 & 0 & 9 \\
\hline 87 & 13 & 1 & 14 \\
\hline 88 & 3 & 1 & 4 \\
\hline 89 & 4 & 1 & 5 \\
\hline 90 & 4 & 1 & 5 \\
\hline 91 & 1 & 0 & 1 \\
\hline 92 & 2 & 1 & 3 \\
\hline 93 & 2 & 1 & 3 \\
\hline 94 & 0 & 1 & 1 \\
\hline 96 & 4 & 0 & 4 \\
\hline 97 & 0 & 1 & 1 \\
\hline \multirow{2}{*}{ Total (N; \%) } & 178 & 49 & 227 \\
\hline & $78.4 \%$ & $21.6 \%$ & $100 \%$ \\
\hline
\end{tabular}


Table 3. The mean age with respect to gender in patients with diagnosed Alzheimer's disease.

\begin{tabular}{cccccc}
\hline & Gender & $\mathrm{N}$ & Mean & SD & $\mathrm{p}$ \\
\hline \multirow{2}{*}{ Age } & Women & 178 & 79.94 & 8.42 & \multirow{2}{*}{0.672} \\
\multirow{2}{*}{ Total } & Men & 49 & 79.39 & 6.58 & \\
\hline
\end{tabular}

where: $\mathrm{p}<0.05$ - statistics significance.

Table 4. Frequency of the diagnosis of Alzheimer's disease with regard to age and gender.

\begin{tabular}{|c|c|c|c|c|c|}
\hline & & & \multicolumn{2}{|c|}{ Age } & \multirow{2}{*}{ Total } \\
\hline & & & $\leq 65$ years old & $>65$ years old & \\
\hline \multirow{4}{*}{ Gender } & \multirow{2}{*}{ Women } & $\mathrm{N}$ & 14 & 164 & 178 \\
\hline & & $\%$ & $7.9 \%$ & $92.1 \%$ & $100.0 \%$ \\
\hline & \multirow{2}{*}{ Men } & $\mathrm{N}$ & 1 & 48 & 49 \\
\hline & & $\%$ & $2.0 \%$ & $98.0 \%$ & $100.0 \%$ \\
\hline \multirow{2}{*}{\multicolumn{2}{|c|}{ Total }} & $\mathrm{N}$ & 15 & 212 & 227 \\
\hline & & $\%$ & $6.6 \%$ & $93.4 \%$ & $100.0 \%$ \\
\hline
\end{tabular}

94 years of age. Among men, there were numerous disease-free gaps, e.g. the first man was diagnosed with Alzheimer's disease at the age of 60 , the next at the age of 72 . Men were most frequently diagnosed with Alzheimer's disease at the age of 76 (7 men), 77 (6 men) and 75 (5 men). Women were most often diagnosed with Alzheimer's disease at the age of 79 and 82 (14 women), 87 (13 women) and 78 (12 women).

The mean age of patients with Alzheimer's disease was $79.82 \pm 8.05$ years. The mean age of women diagnosed with Alzheimer's disease was $79.94 \pm 8.42$, men $79.39 \pm 6.58$ (Table 3).

There were only 15 patients (6.6\%) under the age of 65 including only one man and 14 women. Alzheimer's disease was much more common over the age of 65 (93.4\%) (Table 4).

Dementia in Alzheimer's disease was diagnosed in 210 patients (2.749\%) of all the study participants. It began to be diagnosed at the age of 60 (one male), and in women at the age of 61 (Table 5). Among people with dementia there were 166 women $(79.0 \%)$ and 44 men $(21.0 \%)$. In men, dementia was most commonly diagnosed at the age of 83 ( 5 men), in women at the age of 87 (16 women) and 88 (14 women).

The mean age of people with dementia in Alzheimer's disease was $81.72 \pm 7.73$ years. As shown in Table 6, the mean age was higher in women (82.11 \pm 7.84 years) than in men (80.25 \pm 7.21 years). There were 12 (5.7\%) patients diagnosed with dementia under the age of 65, including only 1 man and 11 women. Dementia in Alzheimer’s disease was diagnosed considerably more frequently over the age of 65 (94.3\%) (Table 7).

\section{Discussion}

Alzheimer's disease belongs to a group of nervous system disorders having the letter $\mathrm{G}$ in the International Statistical Classification of Diseases and Related Health Problems ICD-10. In the current study, the letter G was recognized 1299 times (17.009\%). Dementia in Alzheimer's disease is in a group of mental and behavioral disorders marked with the letter F. The letter F was identified 838 times (10.973\%). According to the latest publication of the Central Statistical Office in Poland, diseases relevant to the assessment of health status of the Polish population, such as infectious and parasitic diseases, cancer and mental disorders are under constant observation [7]. Similar indications concerning psychiatric and behavioral disorders arise from the current study.

Alzheimer's disease is characterized by gradual enhancement of dementia symptoms [8]. According to an Italian study, the mean age of people with dementia in Alzheimer's disease (neurodegenerative dementia) is lower (73.02 \pm 7.40 years) than in the current study (81.72 \pm 7.73 years) [9]. According to a research conducted in the northern part of Greece among village inhabitants at the age of 65 or older, the diagnosis rate of dementia was significantly lower (2.4\%) than in the current study (94.3\%), even when compared to young adults up to 65 years of age (5.7\%) [10]. The early development of dementia in Alzheimer's disease beginning under the age of 65 is related to gene mutations in subsequent generations (sibling, parent, grandparent with Alzheimer's disease) [11]. 
Table 5. The prevalence of Alzheimer's dementia (F00).

\begin{tabular}{|c|c|c|c|}
\hline \multirow{2}{*}{ Age (years) } & \multicolumn{2}{|c|}{ Gender } & \multirow{2}{*}{ Total (N) } \\
\hline & Women (N) & Men (N) & \\
\hline 60 & 0 & 1 & 1 \\
\hline 61 & 3 & 0 & 3 \\
\hline 62 & 3 & 0 & 3 \\
\hline 63 & 3 & 0 & 3 \\
\hline 65 & 2 & 0 & 2 \\
\hline 66 & 0 & 1 & 1 \\
\hline 69 & 1 & 0 & 1 \\
\hline 70 & 1 & 0 & 1 \\
\hline 71 & 1 & 0 & 1 \\
\hline 72 & 2 & 3 & 5 \\
\hline 73 & 2 & 3 & 5 \\
\hline 74 & 3 & 3 & 6 \\
\hline 75 & 4 & 3 & 7 \\
\hline 76 & 4 & 2 & 6 \\
\hline 77 & 9 & 0 & 9 \\
\hline 78 & 9 & 2 & 11 \\
\hline 79 & 6 & 2 & 8 \\
\hline 80 & 10 & 1 & 11 \\
\hline 81 & 11 & 2 & 13 \\
\hline 82 & 11 & 2 & 13 \\
\hline 83 & 8 & 5 & 13 \\
\hline 84 & 3 & 0 & 3 \\
\hline 85 & 4 & 2 & 6 \\
\hline 86 & 4 & 1 & 5 \\
\hline 87 & 16 & 3 & 19 \\
\hline 88 & 14 & 1 & 15 \\
\hline 89 & 8 & 3 & 11 \\
\hline 90 & 5 & 1 & 6 \\
\hline 91 & 5 & 2 & 7 \\
\hline 92 & 4 & 1 & 5 \\
\hline 93 & 2 & 0 & 2 \\
\hline 94 & 3 & 0 & 3 \\
\hline 95 & 4 & 0 & 4 \\
\hline 98 & 1 & 0 & 1 \\
\hline \multirow{2}{*}{ Total (N; \%) } & 166 & 44 & 210 \\
\hline & $79.0 \%$ & $21.0 \%$ & $100 \%$ \\
\hline
\end{tabular}

Table 6. The mean age with respect to gender in patients with dementia in Alzheimer's disease.

\begin{tabular}{|c|c|c|c|c|c|}
\hline \multicolumn{2}{|c|}{ Gender } & \multirow{2}{*}{$\begin{array}{c}\mathrm{N} \\
166\end{array}$} & \multirow{3}{*}{$\begin{array}{l}\text { Mean } \\
82.11 \\
80.25\end{array}$} & \multirow{3}{*}{$\begin{array}{c}\text { SD } \\
7.84 \\
7.21\end{array}$} & \multirow{3}{*}{$\begin{array}{c}\mathrm{p} \\
0.090\end{array}$} \\
\hline \multirow{2}{*}{ Age } & Women & & & & \\
\hline & Men & 44 & & & \\
\hline Total & & 210 & 81.72 & 7.73 & \\
\hline
\end{tabular}

where: $\mathrm{p}<0.05$ - statistics significance. 
Table 7. Frequency of dementia in Alzheimer's disease based on age and gender.

\begin{tabular}{|c|c|c|c|c|c|}
\hline & & & \multicolumn{2}{|c|}{ Age } & \multirow{2}{*}{ Total } \\
\hline & & & $\leq 65$ years old & $>65$ years old & \\
\hline \multirow{4}{*}{ Gender } & \multirow{2}{*}{ Women } & $\mathrm{N}$ & 11 & 155 & 166 \\
\hline & & $\%$ & $6.6 \%$ & $93.4 \%$ & $100.0 \%$ \\
\hline & \multirow{2}{*}{ Men } & $\mathrm{N}$ & 1 & 43 & 44 \\
\hline & & $\%$ & $2.3 \%$ & $97.7 \%$ & $100.0 \%$ \\
\hline \multirow{2}{*}{\multicolumn{2}{|c|}{ Total }} & $\mathrm{N}$ & 12 & 198 & 210 \\
\hline & & $\%$ & $5.7 \%$ & $94.3 \%$ & $100.0 \%$ \\
\hline
\end{tabular}

The research into Alzheimer's disease conducted in Korea shows that the mean age of study participants was $73.5( \pm 7.3)$ and the disease was diagnosed more frequently in women $69.4 \%$, the values being lower than those in the current study (79.82 \pm 8.05 years; $78.4 \%$ women) [12]. Even a lower mean age of patients diagnosed with Alzheimer's disease was reported from Japan (71.1 \pm 9.7), with a decreased percentage of women (52.5\%) [13].

A comparison with the population data from the United States showed that there were $0.04 \%$ of people diagnosed with Alzheimer's disease at the age of 65 and $96.15 \%$ over the age of 65. Our results present a similar diagnosis rate for patients at the age over 65 (93.4\%) and much higher for those under 65 (6.6\%). Research from the USA also showed that women were more frequently diagnosed with Alzheimer's disease than men, which has been confirmed by the current study [14].

Other authors from the USA examined 30 people with Alzheimer's disease and found that patients under 65 differed from those over 65 in topographic patterns of the brain. Younger people and those who reached the age of 65 had largest grey matter atrophy, whereas patients over 65 had the remarkably atrophic hippocampus [15]. Similar conclusions were reported by authors from Italy and Finland [16].

The analysis of ethnic groups shows that ethnic conflicts increase the rate of Alzheimer's disease. Seminal advances in understanding the genetics and pathophysiology of early familial Alzheimer's disease, several lines of evidence suggest that additional genetic factors remain to be identified for this form of disease. The risk of developing Alzheimer's disease over the life time are likely multitude interact of each other genetic and environmental factors, ethnic and cultural differences [17]-[19].

In the current research, 7637 people among 1,201,000 inhabitants of Podlaskie province (6.35\%) showed ADL incompetence at 0 - 40 score in a 100-point Barthel scale.

Among these patients, 227 were diagnosed with Alzheimer's disease (2.972\%) and 210 (2.749\%) with dementia in Alzheimer's disease. Additionally, in the Podlaskie province the non-Polish nationality and ethnicity were declared by $2.8 \%$ of the population, and $3.2 \%$ of people speak other than Polish language at home. Literature also confirms high prevalence of Alzheimer's disease and dementia in Alzheimer's disease associated with cognitive function, behavior and ability to perform daily living activities [9] [20]-[22]. Results of this study were discuss with currently accessible Polish publications where mental disorders in different place are under constant observation.

\section{Conclusion}

The current study confirms the impact of Alzheimer's disease and dementia in Alzheimer's disease on the ability to independently perform activities of daily living. The research suggests that the high rate of Alzheimer's disease and dementia in Alzheimer's disease is caused by ethnicity and nationality differences, associated with learning at home and in schools in the Podlaskie province.

\section{References}

[1] World Health Organization (2009) International Statistical Classification of Diseases and Related Health Problems. ICD-10. World Health Organization, Geneva.

[2] Grossberg, G.T. and Kamat, S.M. (2011) Choroba Alzheimera. Najnowsze strategie diagnostyczne i terapeutyczne. Wydawnictwo Medisfera, Warszawa.

[3] Kiejna, A. (2011) Epidemiologia choroby Alzheimera. In: Leszek, J., Ed., Choroby otepienne, Teoria i praktyka. 
Wrocławska Drukarnia Naukowa PAN, Wrocław, 25-30.

[4] Dziennik Ustaw Rzeczpospolitej Polskiej (2004) Ustawa z dnia 27 sierpnia 2004r. o świadczeniach opieki zdrowotnej finansowanych ze środków publicznych.

[5] Urząd Statystyczny w Białymstoku (2012) Województwo podlaskie w liczbach, Białystok.

[6] Urząd Statystyczny w Białymstoku (2012) Narodowy Spis Powszechny Ludności i Mieszkań 2011. Raport z wyników w województwie podlaskim, Białystok.

[7] Central Statistical Office (2013) Health and Health Care in 2012. Central Statistical Office, Warszawa.

[8] Nestorowicz, J. (2010) Przebieg choroby Alzheimera. In: Paranowski, T., Ed., Choroba Alzheimera, Państwowy Zakład Wydawnictw Lekarskich, Warszawa, 23-32.

[9] Spalletta, G., De Luca V., Padovani A., Rozzini, L., Perri, R., Bruni, A., Canonico, V., Trequattrini, A., Bellelli, G., Pettenati, C., Pazzelli, F., Caltagirone, C. and Orfei, M.D. (2013) Early Onset versus Late Onset in Alzheimer's Disease: Who Is Reliable Cut-Off? Advances in Alzheimer's Disease, 2, 40-47. http://dx.doi.org/10.4236/aad.2013.21005

[10] Tsolaki, M., Kakoudaki, T., Tsolaki, A., Verykouki, E. and Pattakou, V. (2014) Prevalence of Mild Cognitive Impairment in Individuals Aged over 65 in Rural Area in North Greece. Advances in Alzheimer's Disease, 3, 11-19. http://dx.doi.org/10.4236/aad.2014.31002

[11] Wojszel, Z.B., Wilmańska, J., Pecuszok, P. and Konstantynowicz, J. (2012) Jak starzeć się pomyślnie. Publikacja Rządowego Programu na rzecz aktywności Społecznej Osób Starszych na lata 2012-2013 z Ministerstwa Pracy i Polityki społecznej, Białystok.

[12] Seo, S.W., Im, K., Lee, J.-M., Kim, S.T., Ahn, H.J., Go, S.M., Kim, S.-H. and Na, D.L. (2011) Effects of Demographic Factors on Cortical Thickness in Alzheimer's Disease. Neurobiology of Aging, 32, 200-209. http://dx.doi.org/10.1016/j.neurobiolaging.2009.02.004

[13] Shiino, A., Watanabe, T., Maeda, K., Kotani, E., Akiguchi, I. and Matsuda, M. (2006) Four Subgroups of Alzheimer's Disease Based on Patterns of Atrophy Using VBM and a Unique Pattern for Early Onset Disease. NeuroImage, 33, 1726. http://dx.doi.org/10.1016/j.neuroimage.2006.06.010

[14] Alzheimer's Association Report (2014) Alzheimer's Disease Facts and Figures. Alzheimer's \& Dementia: The Journal of the Alzheimer's Association, 10, 47-92.

[15] Frisoni, G.B., Pievani, M., Testa, C., Sabattoli, F., Bresciani, L., Bonetti, M., Beltramello, A., Hayashi, K.M., Toga, A.W. and Thompson, P.M. (2007) The Topography of Grey Matter Involvement in Early and Late Alzheimer's Disease. Brain, 130, 720-730. http://dx.doi.org/10.1093/brain/awl377

[16] Frisoni, G.B., Testa, C., Sabattoli, F., Beltramello, A., Soininen, H. and Laakso, M.P. (2005) Structural Correlations of Early and Late Onset Alzheimer's Disease: Voxel Based Morphometric Study. Journal of Neurology, Neurosurgery \& Psychiatry, 76, 112-114. http://dx.doi.org/10.1093/brain/awl377

[17] Manusouri, L., Klai, S., Fekih-Mrissa, N., Gritli, N. and Mrissa, R. (2013) C677T and A1298C Gene Polymorphisms and Sporadic Early-Onset Alzheimer's Disease. Advances in Alzheimer's Disease, 2, 132-134. http://dx.doi.org/10.4236/aad.2013.24018

[18] Rabinovici, G.D., Furst, A.J., Alkalay, A., Racine, C.A., O’Neil, J.P., Janabi, M., Baker, S.L., Agarwal, N., Bonasera, S.J., Mormino, E.C., Weiner, M.W., Gorno-Tempini, M.L., Rosen, H.J., Miller, B.L. and Jagust, W.J. (2010) Increased Metabolic Vulnerability in Early-Onset Alzheimer’s Disease Is Not Related to Amyloid Burden. Brain, 133, 512-528. http://dx.doi.org/10.1093/brain/awp326

[19] Opala, G. (2011) Epidemiologia otępień w perspektywie prognoz demograficznych. In: Leszek, J., Ed., Choroby otepienne, Teoria i praktyka, Wrocławska Drukarnia Naukowa PAN, Wrocław, 31-41.

[20] Rovio, S., Karehold, I., Helkala, E.-L., Viitanen, M., Tuomilehto, J., Nissinnen, A. and Kivipelto, M. (2005) LeisureTime Physical Activity at Midlife and the Risk of Dementia and Alzheimer's Disease. Lancet Neurology, 4, 705-711. http://dx.doi.org/10.1016/S1474-4422(05)70198-8

[21] Waite, L.M., Grayson, D.A., Piguet, O., Creasey, H., Bennett, H.P. and Broe, G.A. (2005) Gait Slowing as a Predictor of Dementia: 6-Year Longitudinal Data from the Sydney Older Persons Study. Journal of the Neurological Sciences, 229-230, 89-93. http://dx.doi.org/10.1016/j.jns.2004.11.009

[22] Hooghiemstra, A.M., Eggermont, L.H.P., Scheltens, P., Van der Flier, W.M. and Scherder, E.J.A. (2012) Exercise and Early-Onset Alzheimer's Disease: Theoretical Considerations. Dementia and Geriatric Cognitive Disorders Extra, 2, 132-145. http://dx.doi.org/10.1159/000335493 